
the Creative Commons Attribution licence (http://creativecommons.org/licenses/by/4.o/), which permits unrestricted re-use, distribution, and reproduction in any medium, provided the original work is properly cited. doi:10.1017/SoO22046920002602

\title{
Taxes, Wagenburgs and a Nightingale: The Imperial Abbey of Ellwangen and the Hussite Wars, I 427-I 435
}

by MARK WHELAN

King's College London

E-mail: mark.whelan@kcl.ac.uk

Drawing upon unpublished financial accounts, this article sheds new light on how an ecclesiastical institution in southern Germany navigated the tense military and political environment of the Holy Roman Empire during the Hussite wars. The accounts of Ellwangen Abbey offer a compelling window into how its community dealt with a series of military, economic and diplomatic challenges - from raising extraordinary war taxes and hosting the visiting emperor-elect, to equipping its own military contingent-encouraging a reassessment of the burdens borne by ecclesiastical foundations during the Hussite era and offering new perspectives on how holy war impacted on daily life in smaller communities in Central Europe.

DRTA $=$ Deutsche Reichstagskten, Ältere Reihe, ed. Dietrich Kerler and others, Munich 1867-2001; StAL = Staatsarchiv Ludwigsburg, Ludwigsburg; HHSTA, RR=Haus-, Hof und Staatsarchiv, Vienna, Reichsregisterbücher

I came across the manuscript upon which this article is based by chance while conducting research in the Staatsarchiv Ludwigsburg (Baden-Württemberg) for the Leverhulme-funded project, 'Bees in the Medieval World: Economic, Environmental and Cultural Perspectives', led by Alexandra Sapoznik at King's College London (Leverhulme Trust RPG-2018-o8o). I am grateful to Alex for her permission to expand this find into an article and for her consistent support. I am also grateful to Matthias Ludwig (Domstiftsarchiv Naumburg) for sharing an offprint of his work, to Hannes Kleineke (History of Parliament Trust) for identifying some of the more obscure dating clauses in the manuscript, to Corinna Knobloch (Staatsarchiv Ludwigsburg) for facilitating access to archival materials, and to the anonymous reviewer of this article for their helpful comments and suggestions. 
I

n 1431 the Benedictine abbey of Ellwangen in Swabia outfitted a small company of men and artillery for war. The expenses involved were as diverse as they were onerous, including the purchase of wagons, horses, gunpowder, shot, armour, victuals, cooking implements, crossbows, swords and spears and no less than 5,500 arrows. The reason for this expenditure was the Hussite wars raging some hundred and fifty miles to the east, which in 1419/20 had freed the kingdom of Bohemia from allegiance to pope and king and threatened the ruling elites of Christendom ever since. ${ }^{1}$ Ellwangen's military contribution was part of a broader effort in the Holy Roman Empire in 1430 and 1431 to marshal the resources of major cities and lordships - secular and ecclesiastical-into a military force that could extirpate Hussitism. ${ }^{2}$ Drawing upon unpublished financial accounts, this article sheds new light on how an ecclesiastical institution in the empire reacted during a time of war to the unexpected demands on its resources, finances and information-gathering abilities. Ellwangen's accounts not only record the fortification of one of their estates and the equipping of a military contingent, but offer a compelling window into how the abbey dealt with the series of economic, diplomatic and logistical issues sparked by the heretical movement-from raising extraordinary war taxes and hosting the visiting emperor-elect, to sourcing copies of Hussite leaflets in circulation. Ellwangen was one of twenty-nine abbeys commanded to provide military forces in the anti-Hussite crusade of $143^{1}$ and, as such, its experience can inform us more generally about how institutions similar in resources and stature navigated the difficult economic, diplomatic and military environment brought to the German-speaking regions neighbouring Bohemia by the outbreak of Hussitism. From a broader perspective, therefore, the experience of Ellwangen offers fresh perspectives on how smaller communities across the southern and eastern stretches of the Holy Roman Empire experienced the Hussite wars and the difficulties they faced in satisfying the often competing demands of regional, imperial and ecclesiastical politics in a region marked by holy war.

Communities and leaders across the Holy Roman Empire and beyond had grappled with the Hussite threat for almost a decade by the time Ellwangen's account book begins recording incomes and outgoings in 1427. The year after Hussite factions seized power in Prague in 1419,

1 The terms used to describe military and religious developments pertaining to Bohemia between 1419 and 1434 remain contested, and for clarity this article will use the term 'Hussite wars'. For discussion see Pavel Soukup, 'Religion and violence in the Hussite wars', in W. Palaver, H. Rudolph and D. Regensburger (eds), The European wars of religion: an interdisciplinary reassessment of sources, interpretations, and myths, Farnham-Burlington, VT 2016, 19-44 at pp. 19-20.

${ }_{2}$ For background see František Śmahel, Die Hussitische Revolution, trans. Thomas Krzenck, Hannover 2002, iii. $15^{16-20 .}$ 
Sigismund of Luxemburg, the Holy Roman Emperor elect and claimant to the Bohemian throne, launched the first of eventually five papallysanctioned crusades aimed at crushing the heresy and securing his inheritance. 3 The first crusade met with failure in the autumn of 1420 , and subsequent military expeditions launched by shifting alliances of Catholic powers throughout the early and mid- 1420 encountered the same fate. 4 Buoyed by military success and encouraged by divisions in the Catholic camp, Hussite armies then went on the offensive in 1426 when they launched their 'glorious rides' ('spanilé jízdy'), beginning with invasions of Silesia and Austria, but soon expanding in scope to include raids into Franconia, Bavaria, Upper Swabia, Upper Hungary, and even the possessions of the Teutonic Order on the Baltic littoral.5 By 1427, therefore, when Ellwangen's responses to the Hussite threat enter focus, communities across the region had been involved in contributing troops to repeated and failed invasions of Bohemia and forced to look to their own local defence. They were, furthermore, now actors in complex and sprawling networks of correspondence, discussion and negotiation with their neighbours and regional and international leaders regarding how best to combat Hussitism, including how to raise the resources necessary both for selfdefence and to eradicate the threat. ${ }^{6}$ These developments would only intensify in the later 1420 s and early 1430 , for these years witnessed ambitious plans for an empire-wide tax to fund an army capable of defeating the Hussites as well as the 'fifth' and final crusade of 1431, numerically the largest army that Catholic powers would bring to the field throughout the conflict. 7 The abbey of Ellwangen and its monastic community took part in these developments and contributed to other efforts aimed at combatting Hussitism too. At the same time, the threat of Hussite raids never receded, and many communities - Ellwangen included - needed to tread carefully, dispatching forces and money to support large-scale invasions of Bohemia in order to please influential regional leaders, while retaining sufficient military

3 For a summary of events see Alexandra Kaar, Wirtschaft, Krieg und Seelenheil: Papst Martin V., Kaiser Sigismund und das Handelsverbot gegen die Hussiten in Böhmen, Vienna 2020, 54-65. For a concise summary see Soukup, 'Religion and violence', 21-4.

4 Kaar, Wirtschaft, 56-6o.

5 On these expeditions see ibid. 60-1, and Martin Pjecha, 'Spreading faith and vengeance: human agency and the "offensive shift" in the Hussite discourses on warfare', in Zdeněk V. David and David R. Holeton (eds), The Bohemian Reformation and religious practice, $\mathrm{x}$, Prague 2015, $15^{8-184}$, esp. pp. $15^{8-60,1} 7_{1-2}$. See also Thomas Fudge, The magnificent ride: the first Reformation in Hussite Bohemia, Aldershot 1998.

6 The role that the Hussite wars played in intensifying networks of alliance and cooperation in the empire is explored in Duncan Hardy, 'An Alsatian nobleman's account of the second crusade against the Hussites in 1421 : a new edition, translation, and interpretation', Crusades xv (2016), 199-221, esp. pp. 209-11.

7 Both the empire-wide taxation scheme and the fifth Hussite crusade receive significant attention later in the article. 
and financial resources for local security. The abbey's financial accounts offer, therefore, an unparalleled view from the ground level of how a smaller community dealt with being thrust into the veritable swirl of competing military and diplomatic currents and initiatives that marked the tense political environment of the region during the Hussite wars. ${ }^{8}$

The study of Ellwangen's responses to the Hussite movement in the later 1420 and early 143 os is made possible by the chance survival of an account book recording the foundation's incomes and outgoings running between 13 February 1429 and 12 March 1436 (divided into seven accounting years), although some expenses from 1427 and 1428 appear in the first accounting year of the manuscript. 9 Drawn up under the supervision of Konrad Schreiber ('Conrad Schryber'), the secretary of the abbey's accounting office ('rechenampt'), and running to some ninety-one folios, the book has lain relatively unnoticed in the Staatsarchiv Ludwigsburg, has never been published, and has never been put to serious scholarly use. ${ }^{10}$ To be blunt, the lack of attention may be because, at first sight, the account book appears a mundane record filled with repetitive entries recording the quotidian incomes and costs associated with running an abbey and its estatesof most interest, therefore, to economic historians, and what little focus there has been on Ellwangen's economic history has gravitated towards the thirteenth and fourteenth centuries. ${ }^{11}$ But hidden throughout are references to the myriad of military and political developments set into motion when - as Konrad put it himself in one entry for the purchase of gunpowder - 'the frightfulness of the Hussites appeared'. ${ }^{12}$

Konrad's frequent references to matters concerning the Hussites are especially valuable, given the meagre source materials available to shed light on how ecclesiastical institutions - and, in fact, smaller communities in general-responded to the daily financial, political and logistical challenges posed by the heretical movement. What materials do survive from this period generally stem from secular lordships or civic bureaucracies, and Alexandra Kaar's recent work has shed new light on the quotidian

8 The tense regional, diplomatic and political environment is spelled out in Kaar, Wirtschaft, 238-69, esp. pp. 239-51.

9 Now in StAL as B $383 \mathrm{~V} / 9,1428-35$ (hereinafter cited as StAL, V/9).

${ }_{10}$ The codex is neither foliated or paginated, so I have 'silently' foliated the manuscript, beginning with fo. $1 \mathrm{r}$ at the first written folio and stopping at the last folio to bear writing $(91 \mathrm{v})$. The account book is in a hand contemporary to the second quarter of the fifteenth century and on paper with a binding of parchment.

${ }^{11}$ Shami Ghosh, 'The imperial abbey of Ellwangen and its tenants: a study of the polyptych of 1337', Agricultural History Review lxii (2014), 187-209, esp. pp. 189-92.

${ }_{12}$ 'als daz geschray von der Hussen wegen kom': StAL, V/9, fo. 3or. When quoting from the manuscript, I have expanded abbreviations and added capitals and punctuation to make reading easer. Diacritical marks over vowels (including y/ÿ) are represented with umlauts. 
challenges, financial hardships and personal tragedies that could afflict Catholic and Jewish civic communities living and working in a tense war zone perforated with fear of the Hussites. ${ }^{13}$ Although Kaar identifies some individual clergymen whose lives were impacted by the Hussite wars - including the case of one Catholic priest caught dealing in stolen books and manuscripts given to him by Hussites - sources that can shed light on the responses of smaller ecclesiastical communities in general have seldom survived. ${ }^{14}$ The parish book ('Pfarrbuch') kept by a priest in Gebenbach (now in Bavaria), for instance, records events between 1419 and 1437, and bears witness to the financial impact of Hussite raids on the locality, from the theft of beehives to the seizure of church plate, but it is a rare example. ${ }^{15}$ Chronicles and biographies ('gesta') occasionally reference the response of ecclesiastical institutions and their leaders to the Hussite wars: fear of Hussite assault, for example, encouraged the bishop of Naumburg to strengthen the defences surrounding his castle and cathedral in 1427, and the bishop of Eichstätt's biographer included a short report of his lord's campaigning in 1431 which apparently cost him 3,ooo florins. ${ }^{16}$ But such references are infrequent, usually focus on high-profile prelates, and often lack financial and technical detail. It is here where Ellwangen's accounts offer unique and rich perspectives on how smaller ecclesiastical institutions experienced the Hussite wars as a community and as an institution, ranging from the struggles it experienced in delivering its war taxes, its dispatch of monastic servants hundreds of miles distant to secure military apparel and horses, to even paying a travelling singer for a copy of a Hussite tract.

${ }^{13}$ Kaar, Wirtschaft, esp. pp. 239-51. For analysis of financial accounts of secular provenance see Michaela Bleicher, 'Das Herzogtum Niederbayern-Straubing in den Hussitenkriegen. Kriegsalltag und Kriegsführung im Spiegel der Landschreiberrechnungen', unpubl. PhD diss. Regensburg 2004. For a summary see her 'Kriegsführung und Kriegsalltag im Bayerisch-Böhmischen Grenzgebiet: die Hussitenzeit im Spiegel der Quellen des Herzogtums Niederbayern-Straubing', in Franz Machilek (ed.), Die Hussitische Revolution, Cologne 201 2, 235-50.

${ }^{14}$ Kaar, Wirtschaft, 1 71-3, 200-1.

15 Franz Fuchs, 'Dörflicher Alltag in der Hussitenzeit: aus den Aufzeichnungen eines Oberpfälzer Landpfarrers', in Hans-Jurgen Becker (ed.), Der Pfälzer Löwe in Bayern: zur Geschichte der Oberpfalz in der kurpfälzischen epoche, Regensburg 1997, 37-55, esp. pp. $5^{1-4}$. For further analysis see Albrecht Greule, 'Nordbairisch in der Hussitenzeit', in Marina Wagnerová and Boris Blahak (eds), Hussitismus und Grenze: Jan Hus, seine Zeit und Bezüge aus interdisziplinärer Perspektive, Hamburg 2016, 99-117, esp. pp. $105^{-6 .}$

${ }_{16}$ Paule Lange, Chronik des Bistums Naumburg und seiner Bischöfe, ed. Felix Köster, Naumburg 1891, 38. For context see Matthias Ludwig, 'Pro expensis factis contra hussitos seu bohemos: ein Naumburger Hussitensteuer-Register aus dem Jahr 1426', SaaleUnstrut-Jahrbuch xxii $(2017), 13^{-21}$ at pp. 13-14. On the bishop of Eichstätt see Benjamin Arnold, 'German bishops and their military retinues in the medieval empire', German History vii (1989), 161-83 at p. 180. 
Konrad's account book is valuable, furthermore, for it makes possible an understanding of how institutions similar in size and status across the empire that have left little or no source material dealt with the challenges that accompanied the outbreak of Hussitism. Ellwangen was but one in a long list of abbeys (twenty-nine, to be exact) which the imperial Reichstag at Nuremberg called upon to provide contingents for service against the Hussites. ${ }^{17}$ But how these institutions supplied their forces, the cost of doing so, and how they went about gathering information and maintaining contacts with regional leaders in the meantime remains unknown for want of sources. It is here that Konrad's accounts preserve evidence for processes that must have been replicated across the southern and eastern stretches of the empire, but which hitherto have remained unclear. A close study of Konrad's account book, therefore, not only sheds new light on the reactions of smaller ecclesiastical institutions to the Hussite threat and how imperial commands were interpreted and enacted in practice on the ground level, but brings to the fore a source whose provenance and content remains almost unique in the field of Hussite studies. The following sections will offer the first analysis of Konrad's account book and of Ellwangen's experience of holy war in the 1420 and 143 os. Firstly, the article will place the abbey in its regional context and underline how the institution's experience of the Hussite wars can be generalised and applied to the two dozen or so other imperial abbeys that also took part in combatting Hussitism. It will then survey the abbey's collection of the extraordinary so-called 'Hussite tax' in the later 1420 and the subsequent disputes as to its allocation, before examining the visit of Sigismund of Luxemburg, king of the Romans and emperor-elect, in February 1431. It will then assess the abbey's military expenditure in the early 1430 -including its dispatch of a military contingent in summer 1431 as part of the fifth Hussite crusade - before offering a general analysis of the expenses forced upon the abbey in maintaining communications and exchanging sensitive information in the tense environment of the south-eastern Holy Roman Empire during the Hussite wars.

Ellwangen was an imperial abbey founded in the eighth century, situated about twenty miles north-east of Stuttgart. ${ }^{18}$ Its abbot throughout the

${ }^{17}$ DRTA ix, no. 4o8, pp. 530-1. On the Reichstag of 1431 see Hartmut Spengler, 'Der Nürnberger Tag von 1431 und der Beschluss des letzten Hussitenfeldzuges', Mitteilungen des Vereins für Geschichte der Stadt Nürnberg ci (2014), 39-78.

${ }^{18}$ For concision, background is kept to a minimum. Readers desiring more detail are pointed towards Ghosh, 'The imperial abbey', 189-92, and Brigitte Oberle, 'Überlegungen zu den Motiven für die Umwandlung des Benediktinerklosters 
latter period of the Hussite wars was Johann von Holzingen $\left(1427^{-} 5^{2}\right)$, an undistinguished member of the lower nobility who probably stemmed from the settlement of Holzingen in nearby Franconia. ${ }^{19}$ His brother, Heinrich, and sister, Kathrine, appear as frequent visitors to the abbey in Konrad's accounts and followed similar careers: the latter was thrown what appears to be some sort of party when she became an abbess, with Konrad purchasing food and dispensing cash gifts to mark the occasion. ${ }^{20}$ The monks of Ellwangen themselves, like their abbot, were probably drawn from the echelons of local nobility too. A rare insight into conventual life in Ellwangen is offered in the 'serious complaint' ('swerer clage') which Abbot Siegfried (1400-27), Holzingen's predecessor, presented to Sigismund in 1417 while attending the Council of Constance. In his petition he bemoaned how the 'abbey, convent and cloister were much burdened and oppressed' by renegade members who fled from the foundation to take refuge with locals, asking Sigismund to forbid such activity. ${ }^{21}$ Restlessness and flight from monastic communities in the late medieval period was not uncommon, and there is no cause to suspect that the abbey was significantly worse or better in discipline than its contemporaries. ${ }^{22}$ Although the abbey was technically subject directly to king/emperor, the role of protector was delegated to the count of Württemberg, which helps to explain the frequent giving of gifts to and running of errands for Count Ludwig and his mother that appear in Konrad's accounts. ${ }^{23}$ As an imperial abbey it was officially removed from episcopal oversight, but in practice the bishop of Augsburg involved himself in Ellwangen's affairs, particularly in the abbey's collection of the 'Hussite tax'. ${ }^{24}$ Like other imperial abbeys, Ellwangen commanded important albeit relatively modest resources, owning legal rights to local offices and tax farms, rivers and forests, as well as several estates, mills and a bathing house, the latter rented to the citizens of the town of Ellwangen until it burned down in $1434-5 .{ }^{25}$ In the later 1420 Solzingen travelled with an entourage of anywhere between eighteen and twenty-three horse and the abbey was equipped to a high enough standard and was of sufficient

Ellwangen in ein Säkularkanonikerstift im Vorfeld des Fürstenkriegs, 1459/1460', Zeitschrift für Württembergische Landesgeschichte lxxvi (2017), 51-74, esp. pp. 58-6o.

${ }^{19}$ For a summary of the abbey's history see Dieter Stievermann, 'Das geistliche Fürstentum Ellwangen im 15. und 16. Jahrhundert: politische Selbtsbehauptung im Schatten Württembergs', Ellwanger Jahrbuch xxxii (1987/88), 35-47.

${ }^{20} \mathrm{StAL}, \mathrm{V} / 9$, fo. $57 \mathrm{r}$.

${ }^{21}$ HHSTA, RR, F, fos $61 \mathrm{v}-62 \mathrm{r}$, quotations from fo. 61v; calendared in Regesta Imperii, XI: Die Urkunden Kaiser Sigmunds, I 4 Io-1437, ed. Willhelm Altmann, Innsbruck 18961900 , no 2592.

23 For more detail see Oberle, 'Überlegungen', 59. ${ }^{22}$ On the abbey's runaway cook in 1424 see n. 78 below.

25 StAL, V/9, fo. $81 v$. For more on Ellwangen', 59 . ial abbey', $189-91$. 
status to host Sigismund of Luxemburg, king of the Romans and emperorelect, who visited in February $1431 .^{26}$ The overriding impression, overall, is that in the first half of the fifteenth century the abbey, its abbots and its monks, do not appear remarkable in any particular way.

This impression is important to establish, for it colours how representative one should regard the experience of the abbey of Ellwangen during the Hussite wars-or at least in the latter phase covered in Konrad's accounts. As an ecclesiastical foundation, it was neither fabulously wealthy nor grindingly poor, nor remarkable in the status, leadership and protection it enjoyed. Of the twenty-nine abbeys which the Reichstag in 1431 commanded to raise military detachments, twenty-eight were ordered to provide between one and five 'lances', with Ellwangen requested to muster three. ${ }^{27}$ In that context, then, it appears an 'average' abbey, and its experiences can shed light more generally-if still tentatively - on how ecclesiastical institutions similar in resources and stature navigated the difficult economic, diplomatic and military environment brought to the region by the outbreak of Hussitism. In fact over half of the overall 228 contributors listed on the muster roll produced in 1431 were expected to provide five lances or less. In being a comparatively minor player Ellwangen represented the majority experience for contributors across the empire, raising the possibility that the abbey's accounts can similarly illuminate how secular lordships - the majority of whom were likewise minor contributors - raised their forces to meet the Hussite threat.

Konrad's account book records incomes and expenditure from 13 February 1429 and entries directly referring or related to Hussite matters recur into the accounting year running from 1 April 1433 until 12 March $1434 .^{28}$ After the accounting year running from 26 March 1432 until 1 April 1433, however, references to Hussite matters are relatively sparse, and expenses related instead to the general ecclesiastical council then ongoing at Basle appear with greater frequency. This shift reflects the broader development in the Hussite wars of the early and mid-143os, where debate and negotiation between Catholic and Bohemian parties at ecclesiastical councils replaced active military



${ }_{27}$ The exception was Fulda, ordered to provide seven lances: DRTA ix, no. 408, pp. $530^{-1}$.

28 For a summary of the course of the Hussite wars see Soukup, 'Religion and violence', 21-3. For more detail see the standard account: Šmahel, Die Hussitische Revolution. 
engagement. ${ }^{29}$ Between 1429 and 1431, however, Konrad's book frequently refer to Hussite matters, for Ellwangen's accounts bear witness to one of the most ambitious policies devised by leaders in imperial circles in the 1420 s to tackle the Hussite threat: the levying of a so-called 'Hussite tax' across the Holy Roman Empire - the first empire-wide taxation scheme devised - to fund a military campaign. $3^{\circ}$ Konrad's accounts offers a unique perspective on how a comparatively minor institution responded to the economic initiative and ultimately how the abbey's money - caught between the powerplay of the count of Württemberg, the bishop of Augsburg and the authorities at Nuremberg-almost fell victim to competing interests and was never disbursed.

The 'Hussite tax' raised in the later 1420s, termed 'Hussite money' ('Hussengelt') in Konrad's accounts, was the brainchild of the English Cardinal Henry Beaufort, bishop of Winchester and great-uncle to King Henry vI of England. $3^{1}$ Appointed in March 1427 by Pope Martin v to lead the Catholic effort to extirpate Hussitism, Beaufort convened a Reichstag that gathered in Frankfurt that winter. $3^{2}$ Here he secured agreement to impose an ambitious empire-wide tax graduated according to personal wealth payable by every lay Christian aged fifteen or over, with clergy contributing five per cent of their income. 33 Attempts had been made to levy a similar tax in 1422 , but Beaufort's fresh plan placed the burden

${ }^{29}$ On this shift, called the 'Hussite Turn', see Norman Housley, 'Ending and starting crusades at the Council of Basel', Crusades xvi (2017), $115^{-46}$ at pp. $116-17$.

$3^{\circ}$ The 'Hussite tax' in the Holy Roman Empire needs a detailed study, but regional case studies are beginning to reassess the initiative. See, for example, Ludwig, 'Pro expensis factis', 13-2 1; Maximilian Lanzinner, 'Der Gemeine Pfenning, eine richtungsweisende Steuerform? Zur Entwicklung des Reichsteuersystems 1422 bis 1608 ', in Peter Rauscher, Andreas Serles and Thomas Winkelbauer (eds), Das 'Blut des Staatskorpers': Forschungen zur Finanzgeschichte der Frühen Neuzeit, Munich 2012, 261-318, esp. pp. 269-73; and Mihkel Mäesalu, 'Die Steuerforderungen des Heiligen Römischen Reiches an die Kirchenprovinz Riga im 15. Jahrhundert', in Anti Selart and Matthias Thumser (eds), Livland: eine Region am Ende der Welt? Forschungen zum Verhältnis zwischen Zentrum und Peripherie im späten Mittelalter, Berlin 201 7, 259-82, esp. pp. 268-74. On the tax in general see Sabine Wefers, Das Primat der Außenpolitik: das politische System des Reichs im 15. Jahrhundert, Berlin 2013, 109-14.

$3^{11}$ For examples in Konrad's book see StAL, V/9, fos 5v, 7v. On Beaufort's career as anti-Hussite crusader see Mark Whelan, 'Between papacy and empire: Cardinal Henry Beaufort, the house of Lancaster, and the Hussite crusades', EHR cxxxiii (2018), 1-31.

$3^{2}$ On the Reichstag and the historiographic controversies surrounding its development and terminology see Duncan Hardy, 'Tage (courts, councils and diets): political and judicial nodal points in the Holy Roman Empire, c. 1300-1550', German History xxxvi (2018), 381-40o, esp pp. 384-6.

33 Steven Rowan, 'Imperial taxes and German politics in the fifteenth century: an outline', Central European History xiii (1980), 203-17 at pp. 208-11. For the details of the tax see DRTA ix, no. $7^{6}$, pp. 91-110. 
on the individual rather than cities and lordships, and his personal gravitas and energy brought a new impetus to the initiative. 34 The money collected-some 35,00o Rhenish gulden in all-was meant exclusively to pay for mercenaries and soldiers for service against the Hussites, with Margrave Friedrich of Brandenburg, the chief commander of imperial forces, overseeing the organisation of the war chest in Nuremberg. 35

Ellwangen's response to the decisions made at the Frankfurt Reichstag of September-November 1427 is made clear from (undated) entries in the section 'general outgoings' ('Gemains usgeben') for the accounting year between 12 February 1429 and 16 April 1430:

Item, 53 [Rhenish] gulden from the abbey's worth for the twentieth for the Hussites that was agreed at Frankfurt.

Item, 2 [Rhenish] gulden for transport costs to the [bishop's] officer of Augsburg when he rode to the Cardinal of England [i.e. Beaufort] on account of the same money [and] took council with all prelates in the diocese of Augsburg etc. $3^{6}$

It is clear, then, that the abbey raised and paid the tax in line with the commands issued by Beaufort and helped pay the costs borne by the diocesan official involved in negotiation with the prelate, but a close reading of Konrad's accounts reveals that the process of delivering the tax was far from smooth. The exact course and chronology is difficult to ascertain, for entries related to the raising of the 'Hussengelt' are spread across several thematic sections of Konrad's accounts-including 'messenger payment' ('Botenlon'), 'gift money' ('Schenkgelt') and 'general outgoings' - and do not always carry an individual date, but piecing them together into some semblance of a framework is possible. 37 Between February and March 1429, in the section entitled 'transport costs beyond the house by land', various members of the abbey, including Abbot Holzingen, Konrad Schreiber, Konrad von Klingenfels and a certain 'Leo', met members of the bishop of Augsburg's court and the margrave of Brandenburg and attended meetings in Ulm and Nördlingen, where matters concerning the 'Hussite tax' and forthcoming military campaigns

34 Rowan, 'Imperial taxes', 2o8-9.

35 Maximilian Lanzinner, 'Reichssteuern in Bayern im 15. und 16. Jahrhundert', in Johannes Helmrath and Heribert Müller (eds), Studien zum I 5 . Jahrhundert: Festschrift für Erich Meuthen, Munich 1994, ii. 821-44 at pp. 824-5.

$3^{6}$ 'Item liii guldin von der appteÿ nutzung zum zwayntzigstentail an die Hussen, als daz zü Fränckfurt angeslagen ist worden. Item ii guldin an der zerung dem official von Augspurg als er zü dem Cardinal von Engelland rait von desselben gelts wegen umb ratt allen prelaten in Augspurger bistumb etc': StAL, V/9, fo. 16v.

37 These three sections in the accounting year starting 22 February 1428 begin on fos $7 \mathrm{v}, 14 \mathrm{r}, 16 \mathrm{r}$. 
were discussed..$^{8}$ In a document drawn up in early March in Nuremberg listing those registered to pay the Hussite tax, Ellwangen claimed that it was ready to pay. 39

From the perspective of Konrad's account book, preparations were underway. In an entry dated 19 April 1429, Konrad noted that he 'himself rode to Augsburg with the Hussite money, but my lord of Württemberg forbade [this] when Hans [Marstaller] brought the letter on the fourth day before [Saint] George'. $4^{\circ}$ The abbey had not only, therefore, raised the Hussite tax in accordance with the decision made the year before at Frankfurt, but had resolved to send it to the head of their diocese in Augsburg. As the entry from 19 April made clear, however, the count of Württemberg forbade the abbey from dispatching the tax, sending Hansen Marstaller, a member of Ellwangen's community, with a letter saying so. In an entry directly below, dated the same day ('eodem tempore'), a peasant's son ('wirts sun') was paid to show Marstaller the way to Augsburg 'by night' ('bii nacht') and to ride with him to intercept Konrad, presumably to secure his return to the abbey with the money before he had handed it over. $4^{1}$ Marstaller and his guide succeeded, and the money returned. The count has left no correspondence justifying his decision, but it is likely that he held the same fears aired in a letter of Duke Ludwig VII of Lower-Bavaria, who claimed that the money raised by the Hussite tax was needed at home, to help defend his own lands from Hussite depredations..$^{2}$ Hussite strategy had shifted from defensive to offensive in the winter of $14^{26}-7$, with daring and destructive raids into Catholic territories in Austria and Silesia.43 In 1428 Hussite armies returned to Austria and also attacked Upper Hungary, Silesia and the Upper Palatinate. 44 It is probable, then, that in the spring of 1429 regional leaders such as the count of Württemberg feared further attacks and wanted to retain ready sums of cash in their locality in order to raise forces for local defence should the Hussites raid nearby. 45 Here, Ellwangen vividly illustrates an experience that must have been replicated across the region, with smaller communities and lordships caught between their obligations to pay the tax to superiors in Upper Swabia and Franconia who needed the funds to prosecute the large-scale invasion of Bohemia, and their overlords closer to home, who

$3^{8}$ This 'Leo' is probably 'Leo Rÿtknecht', a mounted servant, who appears in the list of salaried members of the abbey's community: ibid. fo. $16 \mathrm{r}$. On the travels of members of the abbey community mentioned above see fo. $5^{\text {r. }}$.

39 DRTA ix, no. 210 , p. $281 . \quad 4^{\circ}$ StAL, V/9, fo. $5^{\mathrm{v} .} \quad 4^{1}$ Ibid.

$4^{2}$ DRTA ix, no. 120, p. 154. For more detail see Bleicher, 'Das Herzogtum Niederbayern-Straubing', $148-9$.

43 Pjecha, 'Spreading faith and vengeance', $15^{8-9}$.

44 The military reasoning behind the Hussite raids is discussed in Kaar, Wirtschaft, 6o-1. 
felt compelled to look to their own defences and to keep ready resources at hand.

Ellwangen's non-payment did not go unnoticed. In a document probably from April or May 1429 drawn up in Nuremberg to record who had paid their Hussite tax and who had not, the compiler noted that the abbeys of Ellwangen and Kaisersheim - both in the diocese of Augsburg - had collected the money, but had been forbidden from distributing it ('das eingenommen gelt nicht herauß zu geben'). $4^{6}$ The abbey of Kaisersheim, then, appears to have been in a predicament analogous to Ellwangen, having collected the tax but ordered by their Wittelsbacher overlords not to release it, although whether they endured the similarly hair-raising experience of dispatching the money only for it to be hastily recalled that same day we do not know. Here the entries in Konrad's book shed light on the processes operating in the locality and, in particular, the involvement of a local figure of note: a certain Master Heinrich Neithart, a priest in Ulm turned political advisor to local ecclesiastical and civic leaders. Exploring Konrad's interaction with Neithart highlights the workings of a more local political landscape-below the contemporary panimperial Reichstags and convocations called by imperial princes such as the margrave of Brandenburg - with its own channels of communication and counsel, traces of which do not usually survive in the sources.

After his abortive journey to Augsburg on 19 April, Konrad contacted Neithart 'on account of the Hussite Money'. Konrad was almost certainly contacting him for advice and information, for the latter was a trusted advisor to the abbey. The abbey paid Neithart a stipend of twenty gulden, yearly on 16 October ('uff Galli'), and disbursed additional sums when he advised upon special matters: earlier that year, for example, Neithart had counselled the new abbot on how best to secure papal confirmation of his recently acquired office, in return for thirty gulden. 47 Neithart advised and provided information and advice to other members of the locality too, including the city councils of several Swabian towns. $4^{8}$ It is not unreasonable to suggest that he counselled other ecclesiastical institutions in the region too. By 30 April Neithart's messengers had arrived at Ellwangen bearing 'letters about the Hussite money', which presumably contained responses to Konrad's initial requests for advice in the aftermath of 19 April. On 7 May more letters 'about the Hussite money' from Neithart arrived in Ellwangen, and on 26 May Konrad journeyed personally to visit Neithart in Ulm 'on account of the Hussite money'. ${ }^{9}$ Konrad then presumably returned to Ellwangen, for on 19 June he ventured once again to Ulm,

$4^{6}$ DRTA ix, no. 2og, pp. $263-4$.

47 StAL, V/9, fo. 4v. For Neithart's stipend see fos $13 \mathrm{r}$, 3or, 54r, 64v, 76r, 88v.

$4^{8}$ See, for example, DRTA x, p. 229 n. 2; nos 234, pp. 389-9o n. 4, $73^{8}$.

49 StAL, V/9, fos 5 v, 8r. 
again 'on account of the Hussite money', to confer with Neithart. $5^{\circ}$ There was obviously plenty of discussion, because on 24 June Konrad and Neithart sent messengers from Ulm to Ellwangen who 'brought my lord [abbot] letters and advice when one wanted to take the Hussite money to Nuremberg' ('briefen und ratt als man das Hussengelds Nüremberg furen wolt'). $5^{1}$ While the content of the discussions and correspondence between Abbot Holzingen, Konrad and Neithart must remain unknown, the likelihood remains that the latter recommended that the abbey should pay the tax, as the following entry dated 25 June illustrates:

Item 2 [Rhenish] gulden 19 shillings 7 heller in costs for Konrad Heffner, Konrad Schreiber, and a servant, to [travel to] Nuremberg with the Hussite money, and also on account of Hansen von Wollmershausen for 21 becher, which was also spent on the Hussite money, on the Saturday after St John the Baptist [25 June] and stayed [there] three days. $5^{2}$

Given that Konrad and his party rode to the Nuremberg 'with the Hussite money' the day after discussions with Neithart, and that there is an entry for the payment for the tax in the same accounting year, it seems safe to assume that the abbey paid its contribution.

Despite only constituting one disbursement of the Hussite tax, the payment rendered by Konrad and his party grows in significance when situated in its context, as it helps defuse - at least in part - some of the negativity surrounding the initiative that began in 1427 . The Hussite tax proved a disappointment to contemporaries and modern historians alike. The chronicler, Andrew of Regensburg, wrote that Beaufort's plans were foolhardy and failed to achieve anything, and modern historians have followed suit: Isenmann derided the Hussite tax of 1427 as a 'failure' and, more recently, Michaela Bleicher has followed in condemning the scheme as a 'fiasco' with Mihkel Mäesalu concluding that it 'failed in all German lands'.53 Maximilian Lanzinner's study of the tax's collection in Bavaria, however, has pointed to how the tax was successfully raised, but was withheld from authorities in Nuremberg by local landholders struggling to fund their own defence in the face of Hussite raids. Lanzinner goes on

$5^{\circ}$ Ibid. fo. 8 r.

$5^{1}$ Ibid.

$5^{2}$ 'Item ii guldin xix B vii heller verzarten Conrat Heffner, Cünrade Schryber und ein knecht mit dem Hussengelt gen Nuremberg, und auch von Hansen von Wollmerßhusen wegen uber xxi becher die sie auch von Hussengelt verzerten, sabato post Johannis Baptiste und lagen drey tag doselbs': ibid. fo. $5^{\mathrm{v}}$.

53 Eberhard Isenmann, 'Reichsfinanzen und Reichssteuern im $\mathbf{1}_{5}$. Jahrhundert', Zeitschrift für Historische Forschung vii (1980), 129-218 at pp. 159-6o. For similar comments about the 'failure' of the tax see his 'The Holy Roman Empire in the Middle Ages', in Richard Bonney (ed.), The rise of the fiscal state in Europe, c. I200-I8I5, Oxford 1999, 243-8o at p. 266; Bleicher, 'Das Herzogtum Niederbayern-Straubing', 148; and Mäesalu, 'Die Steuerforderungen', 273. 
to conclude that much of the taxation was indeed used by the dukes of Bavaria (or their allies) to fund military efforts aimed at the Hussites, and in that sense the initiative was a success. 54 Matthias Ludwig has similarly pointed to the successful raising of the tax in Naumburg as evidence of the impact that the Hussite threat had in moving contemporaries, both secular and ecclesiastical, to action.55 A close reading of Konrad's accounts points to a similarly complex situation in Swabia, streaked both with success and failure: Ellwangen, at least, raised and paid the tax, notwithstanding attempts to withhold the tax made by a secular overlord. Thanks to a letter edited and printed in the $187 \mathrm{os}$, the diocese of Augsburg has come to represent one of the worst offenders in the non-payment of the Hussite tax. $5^{6}$ The letter concerned was written by the collectors of the Hussite tax in October 1432, who account for the diocese's collection of and subsequent withholding of the funds from the authorities in Nuremberg on account of disagreements with local noble groups that appeared as petty at the time as they have to scholars today. Scholars of imperial taxation would do well to consult overlooked sources such as Konrad's accounts, for institutions in the diocese of Augsburg were not all as lax in paying their tax. From a broader perspective, the efforts demonstrated by institutions such as Ellwangen to deliver the tax in the face of local interference attest to the resonance of Beaufort's call of 1427 , a resonance often ignored by scholars more eager to seek out evidence of disenchantment.

In addition to the Hussite tax and the military costs of $143^{\circ}$ and $143^{1}$, the region was encumbered with yet another financial burden, and one from which not even the relatively isolated Ellwangen could escape: Sigismund of Luxemburg himself. Although Sigismund had declared himself too unwell to take the field against the Hussites, he still felt fit enough to offer moral support to his beleaguered subjects in person. He therefore ventured out of his other kingdom of Hungary in summer 1430, spending the better part of two years touring through Franconia, Bavaria and Swabia.57 Here he split his time between visiting religious sites, feasting and raising awareness of the Hussite threat, advising any who would listen on how best to proceed against the heretics. $5^{8}$ Sigismund enthusiastically described his travels through Upper Swabia and along the Bodensee in the winter of 1430 and spring of 1431 as being of 'great and bountiful use to the matters of the holy Reich', but

54 Lanzinner, 'Reichssteuern in Bayern', 825.

55 Ludwig, 'Pro expensis factis', 15 .

${ }^{6}$ DRTA ix, no. 215 , pp. $283-4$.

57 On Sigismund's itinerary during these years see Pál Engel, Itinerarium Sigismundi regis imperatorisque (1382-I437), Budapest 2005, $125^{-7}$.

$5^{8}$ For background see Oliver Daldrup, Zwischen König und Reich: Träger, Formen und Funktionen von Gesandtschaften zur Zeit Sigmunds von Luxemburg (I4IO-I437), Münster 2010, 308-17. 
his contemporaries waiting for him in Nuremberg were not so convinced, especially in light of Sigismund's poor management of affairs in $1429.59 \mathrm{In}$ spring of that year, Sigismund had met with a Hussite delegation in Bratislava to discuss the possibility of a ceasefire and begin tentative moves towards bringing the conflict to a close. ${ }^{60}$ No concrete agreements were reached and the discussions broke down in anger, with Sigismund fruitlessly declaring another military campaign and the Hussites promising retaliation. The Catholic expedition met with failure that summer, while Hussite raids across the winter of 1429-30 cut swathes of destruction through Meissen, Saxony, Thuringia, the Upper Palatinate and Franconia. ${ }^{61}$ Sigismund's tour of the south-eastern stretches of the empire in 1430 and 1431 was, therefore, undertaken amid rising dissatisfaction in imperial circles at his haphazard management of affairs and diplomatic miscalculations that had poured more hardship upon the region. ${ }^{62}$

After suffering the fallout from Sigismund's diplomatic miscalculations in the winter of $1429 / 30$ in the form of Hussite depredations, communities across the southern and eastern stretches of the empire now had to bear the additional burden of paying for the king's visit to the region. Throughout his perambulations, Sigismund expected others to provide him with gifts and accommodation befitting to his status and to contribute to the upkeep of his itinerant and expensive court: an eyewitness account of Sigismund's visit to a monastery in Bavaria in 1430 emphasised his significant retinue, formed as it was of 'Hungarians, Turks, Germans, Bohemians and people of other diverse nations' ${ }^{63}$ The burden fell particularly on institutions that enjoyed imperial immediacy and thus a closer bond with the Roman king, such as imperial free cities and imperial abbeys. To take one example, Sigismund based himself in Nuremberg, an imperial free city and the muster point for successive campaigns against the Hussites, for months at a time in order to attend to military and diplomatic matters. By summer 1431 Sigismund had run up debts owed to the town council of Nuremberg amounting to around 9,ooo Rhenish gulden. ${ }^{64}$ Ellwangen's accounts offer fresh perspectives on the costs associated with accommodating royalty in the empire, underlining how smaller communities across the region with less sophisticated credit mechanisms and financial resources none the less needed to find the money to distribute appropriate largesse, even if they only played host to

59 For the quotation see DRTA ix, no. 393, p. 503. For discussion see Jörg K. Hoensch, Kaiser Sigismund: Herrscher an der Schwelle zur Neuzeit, I368-1437, Munich $1996,362-3$.

60 Hoensch, Kaiser Sigismund, 355-7. For further references and context see Kaar, Wirtschaft, 6o-1. $\quad{ }_{1}^{6}$ Kaar, Wirtschaft, 61. ${ }^{62}$ Hoensch, Kaiser Sigismund, 358-9.

${ }^{63}$ Anonymous, 'Oberaltaicher Zusätze zur Chronica pontificum et imperatorum Romanorum', in Andreas von Regensburg, Sämtliche Werke, ed. Georg Leidinger, Munich 1903, $705^{-6 .}$

${ }^{64}$ Hoensch, Kaiser Sigismund, 366-7, $5^{87}$ n. 45 . 
the king for one day. The abbey, in the end, could not escape Sigismund's itinerary nor his expensive court, and around St Blasius' day (3 February) in 1431 the king visited the abbey on his return to Nuremberg to oversee last minute preparations for the military campaign that would be launched that August. ${ }^{6} 5$

As Konrad's entries make clear, playing host to royalty was not cheap, and rivalled the abbey's expenditure on equipping their military contingent in the months after his departure. As well as a cash gift and a gilded cup worth together 1 oo gulden for 'our lord the king', Konrad also purchased wine from the Alsace and the Neckar regions as well as fish, meat, oats and 'other things', for consumption by Sigismund and his household. ${ }^{66}$ The abbey's generosity in gifting sums of cash extended beyond the royal visitor to include members of his retinue too: Caspar Slick, his chancellor, received ten gulden, and his court herald ('quatterloch') two gulden. This generosity, overall, amounted to just under 148 Rhenish gulden. These expenses Konrad entered under the rubric 'gift money' ('Schenckgelt'), a section which appears yearly, although the royal visit was costed separately from the routine expenditure of that year. When situated in context, the scale of the largesse shown the royal visitor and his retinue was considerable. Excluding the costs of Sigismund's visit, on average, across the six accounting years in the book, Konrad dispensed gifts and bribes under 'gift money' to a total value of just over 194 gulden, meaning an average outgoing of around thirty-two gulden per year. The $14^{8}$ gulden dispensed to entertain, feed and water the royal visitor, was therefore a significant expense, and one probably indicative of the financial burdens borne by smaller ecclesiastical and civic communities across the region that likewise hosted the imperial entourage. Within a few months after Sigismund's departure, however, Ellwangen faced yet greater costs when it equipped and dispatched its small force to muster at Nuremberg, and it is to the military contingent that we now turn.

\section{III}

In the Hussite wars, the raising of military forces for major campaigns in the Holy Roman Empire was based on a muster list where secular and ecclesiastical lordships and cities were commanded to provide a set number of lances ('glefen') at their own expense for service against the Hussites. Technically speaking, a lance was a small fighting unit composed of four men: an armoured rider, a crossbowman (or conventional archer), a soldier armed with sword and spear and a servant. ${ }^{67}$ The muster lists

\footnotetext{
${ }_{5}$ StAL, V/9, fo. $45^{\mathrm{v} .} \quad{ }^{66}$ Ibid. $\quad{ }^{67}$ Hoensch, Kaiser Sigismund, $5^{83}$ n. $5^{\text {o. }}$
} 
agreed at the Reichstag of Nuremberg in February and March 1431 foresaw the raising of 8,41 7 lances (around 32,000 men overall), although much of this number was fanciful, assuming somehow, for example, that the duke of Burgundy would send 4 oo lances and the distant Grandmaster of the Teutonic Order on the Baltic coast would send the same. ${ }^{68}$ Nevertheless, the field army assembled in summer $143^{1}$ proved large in practice, swelled by the retinues and cavalry contingents brought by many of the secular lords - not to mention the papal representative, Cardinal Cesarini, whose personal guard amounted to 3 oo lancers-and artillery trains (wagenburgs) provided by many of the participants, with modern estimates of the force approaching some 40 ,ooo men. ${ }^{69}$ The abbey of Ellwangen was to provide three lances. Although such a contingent might appear insignificant, the army foreseen in the muster roll was largely one of minor players such as Ellwangen, with the majority of participants providing small contingents. Because the electoral princes and towns leave the greatest footprint in the printed source editions of the nineteenth and early twentieth centuries, historians have largely focused on their preparations and contingents to the detriment of smaller contributors, so much so that imperial abbeys received no mention in Hartmut Spengler's recent study of the proceedings of the Nuremberg Reichstag in $1431.7^{\circ}$ Excluding the sixty-seven cities who were bundled together to provide 1,ooo lances, of the 228 other participants in the muster roll (including fanciful ones who never appeared, such as the Grandmaster of the Teutonic Order) just over half (116) were expected to provide five lances or less. The raising of Ellwangen's force, therefore, reflects the majority experience of contributors in the imperial army. It is here where a close analysis of Konrad's account book is so fruitful, for it sheds light on the manner in which a type of ecclesiastical institution usually forgotten by scholars raised its military contribution, and helps nuance the historiographic picture by pointing to the preparations of smaller contributors to the imperial host.

Making sense of Ellwangen's military expenditure is difficult as payments are spread across several accounting years. The margrave of Brandenburg made Ellwangen aware of his plans for a campaign against the Hussites in early October 1429 when his messengers delivering the news stopped off at

${ }^{68}$ DRTA ix, no. 408 , pp. $5^{28}$, 533. The debates at Nuremberg can be followed in Spengler, 'Der Nürnberger Tag', 56-68; planned Burgundian participation in Werner Paravicini, 'Von der Preußenfahrt zum Hussitenkreuzzug', in Bernhart Jähnig (ed.), Beiträge zur Miliärgeschichte des Preussenlandes von der Ordenzeit bis zum Zeitalter der Weltkriege, Marburg 2010, $121-60$ at pp. 140-3.

69 On Cesarini's guard see Whelan, 'Between papacy and empire', 5. On wagenburg contingents and numerical estimates see his 'Walter of Schwarzenberg and the fifth Hussite crusade reconsidered (1431)', Mitteilungen des Instituts für Österreichische Geschichtsforschung cxxii (2014), 322-35 at pp. 328, 332.

$7^{\circ}$ Spengler, 'Der Nürnberger Tag'. 
the abbey on their way to Stuttgart. ${ }^{71}$ It seems that from then on Konrad, using members of his own community as well as one of the abbey's trusted allies and confidantes, a certain Hansen von Wollmershausen, began purchasing military apparel and provisioning one of their estates with victuals and ammunition. Throughout 1429 and 1430 the abbey sent members of its community to the margrave's court and other local meetings 'to find out about the Hussites' ('zü erfaren von der Hussen wegen'), and Abbot Holzingen himself attended discussions at Nuremberg in the summer of $143^{0.7^{2}}$ In the run-up to the imperial campaign in summer 1431 (the so-called fifth Hussite crusade) Hansen was similarly present in Nuremberg for at least April and May, and before then, in February, messengers were sent to the margrave's court at Cadolzburg to discuss the Hussites.73 Messengers were similarly dispatched in the months that followed to gain news 'of the Hussite campaign' ('von des hussen zugs') once the expedition had crossed into Bohemian territory on 1 August. 74 Most of the expenses for the outfitting of the contingent sent on campaign with the primary imperial force in the summer of 1431 were gathered by Konrad under the heading 'expenses and [costs] for the campaign against the Hussites' ('Zerung und umb zuig an die Hussen'). 75 This section was entered into the accounting year running from 26 March 1432 until 1 April 1433, but we can assume that this reflects expenses incurred the previous year, for there was no campaign in $1432 / 33 .{ }^{6}$ An exhaustive analysis of the abbey's military activities lies beyond the scope of this study: instead, this section will focus on the processes underlying its sourcing of its equipment and what this says about the nature of Ellwangen's mobilisation more generally.

Much of the military preparation was undertaken by Konrad himself and Hansen von Wollmershausen ('Wollmerßhusen'). Hansen probably stemmed from the lesser noble family of the same name with roots in nearby Crailsheim, and in a letter of Abbot Siegfried in 1424 is given the appellation 'young lord' ('junckhern').77 Hansen and his relations,

$7^{1}$ 'Item viij $\beta$ dem stehelin mit mins herrn Marggraven brieff gen Stutgarten als er die raise wider bot do man gen Burlesvob wolt sein Dominica ante Symonis et Jude': StAL, V/9, fo. 9r. Konrad's scribe has garbled the margrave's location of Baiersdorf ('Baierstorff') at time of writing as 'Burlesvob': DRTA ix, no. 184, p. 220 . The expenses released by the margrave of Brandenburg for his own messengers can be followed in a contemporary account book printed in Miloslav Polivka, "Liber Tewtonicorum des Ausgebens" pramen k financování válek proti husitům z let 1428-1431', in Jaroslav Pánek (ed.), Vlast a rodný kraj v díle historika: sbornik prací žáků a prátel věnovaný profesoru Josefu Petránovi, Prague 2004, 231-59, esp. pp. 249-51.

$7^{2}$ For examples see StAL, V/9, fo. 24r. On Holzingen's attendance at Nuremberg see DRTA ix, no. $34^{2}$, p. $43^{2} .{ }_{73}$ StAL, V/9, fos $25^{\mathrm{v},} 38 \mathrm{v}-39^{\mathrm{r}} .{ }^{74}$ Ibid. fo. 5 or.

75 Ibid. fo. $47 \mathrm{v}$.

$7^{6}$ On the campaign see Whelan, 'Walter of Schwarzenberg', 322-33.

77 StAL, B 389 , U 861. 
notably Burckhart von Wollmershausen, arbitrated on Ellwangen's behalf in legal disputes of interest to the abbot and abbey: in 1424, for example, Wollmerhausen witnessed the letter of reconciliation between Abbot Siegfried and his renegade cook, who had returned to the abbey after escaping with his sister-in-law for reasons that remained unclear. $7^{8}$ From Konrad's accounts we can see that Hansen accompanied the abbot (and, on occasion, the abbot's brother) to important meetings and also negotiated on his behalf, delivered letters and messages and undertook other tasks of a special nature, such as escorting women and men of high status to and from the abbey.

Equipping a military contingent was far from a quotidian occurrence for the abbey, a fact illustrated by the need for their servants and allies to venture far and wide to secure suitable horses and weaponry that local smithies and stables could not provide. Of all the abbey's community and allies, Hansen travelled most extensively, venturing several hundred miles east to Hungary, where he purchased three horses for 100 Rhenish gulden in October 1429.79 Hansen's sourcing of horses in distant Hungary reflected the difficulty in procuring horses suitable for campaigning in a region that had experienced a decade of warfare. In a similar fashion, one of the abbey's servants, a certain 'Josen', made the round trip of over 6oo miles to Vienna from where he brought back two horses costing just under forty-nine gulden ('umb zwaÿ pferd, die er von Wienn pracht'). ${ }^{80}$ The abbey purchased another three horses at a combined cost of fifty gulden, although their place of purchase was not noted. The price difference between horses purchased for campaign and horses for use by the abbey more generally was significant. The equine purchased for the abbey's huntsman ('jäger') and cellarer to share between them cost only eight gulden, but the steed for a certain 'Slumpen', a mounted soldier who would fight the Hussites in summer 1431, cost seventeen gulden. ${ }^{81}$

Ellwangen was similarly reliant on the markets of important cities in Swabia and Franconia for weaponry, armour and the outfitting of their wagons, and in particular specialist centres for smithying and metallurgy in nearby Nördlingen, some twenty miles south-east of Ellwangen, and Nuremberg, roughly sixty miles north-east of the abbey. Hansen purchased two steel suits of armour ('zwaÿ stëhline pantzer') at six gulden apiece in Nuremberg in mid-November 1429 , while a servant of the abbey sourced a similar suit of armour for nine gulden in the markets of Dinkelsbühl, some fifteen miles to the north-east of Ellwangen, and another for eight gulden and five shillings from Pappenheim, in Bavaria. ${ }^{82}$ Two pieces of

$7^{8}$ Ibid. U 862. For further examples see U 293, 857, 866.

79 StAL, V/9, fo. $12 \mathrm{v}$. 80 Ibid. fo. $42 \mathrm{r}$.

82 Ibid. fos $12 \mathrm{v}, 3$ or.

${ }^{81}$ Ibid. fos 3 or, 42 r. 
armour that were probably some form of armoured helm in an 'English' style, whatever that may have been, were refashioned too ('zway englischen hubern zu segen und $\mathrm{u} \beta$ zuberaiten'). ${ }^{83}$ Konrad Heffner travelled to Nördlingen where he secured two cavalry lances ('ii rennenspieß'), and another of the abbey's community fetched six more from Nuremberg. ${ }^{8} 4$ The fact that Konrad entered expenses of four shillings around midOctober 1430 for a journey that he took to Nördlingen to discuss matters with the 'swordsmith' ('swertfeger') suggests that he purchased some blades there..$^{85}$ It may have been this same swordsmith who prepared two swords the same year at the behest of Holzingen, although where Konrad sourced the sword given to Slumpen 'for when he campaigned against the Hussites' ('do er an die Hussen zoch') is not clear. ${ }^{86}$ The source of Josen's purchase of 1,5 oo arrows and a crossbow with its loading mechanism and sling ('ein armprost und kocher und gurtel') is likewise unclear, but the refurbishment of twelve old crossbows ('alten kruckenarmprosten') in the abbey's possession was undertaken by the local crossbow craftsmen ('Snitzer'), presumably in Ellwangen, who also provided new drawstrings and bindings. ${ }^{87}$ Although there is no evidence for the production or storage of artillery in Konrad's account books, that he purchased $6 \mathrm{lb}$ of sulphur for manufacture into 'cannon powder' ('zü puchsen pulver') and brought 1,059 lb of lead to make into balls (i.e. turn into shot: 'plÿs zü kugeln') from the markets in Dinkelsbühl and Nordlingen in September 1430 suggests that the abbey had the appropriate weaponry to make use of it. ${ }^{88}$

Most of these purchases were probably made in preparation for the military campaign in summer 1431, although some of the equipment could have been destined for the abbey's fortified estate of Tannenberg (also called Büherltann), some fifteen miles north-west of Ellwangen. In an undated entry in the accounting year running between 16 April $143^{\circ}$ and 1 April 1431, Konrad notes that he purchased twenty-seven and a half aymer of cooking wine for Tannenberg, "when one provisioned the castle on account of the Hussites' ${ }^{89}$ In a similarly undated entry in the same accounting year, Josen arranged for the delivery of 4,00o arrows, half to Kochenberg and half to Tannenberg, and the building supplies transported from Nuremberg to Tannenberg might have been intended to strengthen the fortifications. $9^{\circ}$ Alternatively, Tannenberg may have

\footnotetext{
${ }_{83}$ Ibid. fo. 4 6r. $\quad{ }^{84}$ Ibid. fo. $12 \mathrm{v} . \quad{ }^{85}$ Ibid. fo. $25^{\text {r. }} \quad{ }^{86}$ Ibid. fo. $5^{8 \mathrm{r} .}$

87 Ibid. fos $31 \mathrm{v}, 42$ r.

88 On lead and its importance in the Hussite wars see Kaar, Wirtschaft, $16_{3}$.

89 'Item xi guld dem Fritzen Contzen vom Mullin umb xxviij aymer kochen weins haller; ych komen gen Tannenberg als man das sloß spÿst von der Hussen wegen, darnach sint sie herkomen': StAL, V/9, fo. 28 r. 
been one of the bases where the abbey stockpiled its military supplies in preparation for the campaign in 1431 .

The detailed expenses for the campaigning in 1431 were collected by Konrad under the rubric the 'campaign against the Hussites' ('zuig an die Hussen'), and includes eighteen entries running across two folios. $9^{1}$ They reveal that the imperial abbey outfitted its force to fight in the manner of a wagenburg, where wagons mounted with artillery and defended by men-at-arms and crossbowmen would lock together in defensive formations, just like the contingents fielded by the major ecclesiastical and secular lordships and imperial cities. $9^{2}$ The abbey outfitted several campaign wagons ('raiß wagen') with 'chains and other things' ('demselben wagen zü beslagen und mit ketten und allen sachen uß zürüsten') and $24^{2}$ ells of linen and canvas. The wagons were also equipped with flags, wine and other paraphernalia, including two bottles for storing fluids on campaign ('raiß flaschen'), some sort of container for storing food ('spyß legeln'), three cooking pots, two pans and two spoons and a further 115 ells of cloth to fashion into tents ('zum zelt').93 Again, Ellwangen's dependence on regional centres of expertise surfaces again, for some of the preparatory work was done in 'the smithies in Nordlingen' ('die hütten zü Nordlingen'), and the food storage and cooking equipment was purchased in Nördlingen and Nuremberg. The horses that the abbey had painstakingly gathered from Hungary, Vienna and elsewhere were well catered for, with Konrad recording the purchase of over 100 horseshoes ('hüfysen'), 1,ooo horse-shoe nails ('hüffnagel'), and saddles, as well as the costs of metalwork, tent equipment and 119 ells of cloth to create special horse shelters ('rosßhutten') that could be erected on the move.

Seen from a broader perspective, these expenses, when placed together, point to important developments. The investment in gunpowder weaponry and wagenburgs was a salient development of the Hussite wars, for it was vital that imperial forces responded to the Bohemians' effective use of artillery. An imperial eyewitness at the siege of Žatec in $14^{21}$, to take one example, recorded between 100 and 150 casualties daily in the besieging force on account of the unrelenting cannon fire from Bohemian forces, which the he estimated at eight hundred shots a day.94 Scholars, such as Bleicher, have emphasised the significant expense involved in sourcing

$9^{1}$ Ibid. fos $49^{-}-5$ or.

$9^{2}$ On wagenburgs in the Hussite wars see Volker Schmidtchen, 'Karrenbüchse und Wagenburg: Hussitische Innovationen zur Technik und Taktik im Kriegswesen des Spätenmittelalter', in Volker Schmidtchen and Eckhard Jäger (eds), Wirtschaft, Technik und Geschichte: Beiträge zur Erforschung der Kulturbeziehungen in Deutschland und Osteuropa, Berlin 1980, 83-108.

94 Hardy, 'An Alsatian', $215^{-17}$. 
firearms and cannon in the Hussite wars, and it has been argued that the better funded civic contingents bore the brunt of this investment in new technology, even if imperial handling of this technology proved lacklustre on the battlefield.95 Konrad's accounts reveal that institutions of more modest means, such as Ellwangen, took part in this process of modernisation too. The accounts also reveal that an imperial abbey had the resources and knowledge necessary to secure the expertise and apparel to meet the obligations laid down at Nuremberg, and from a broad hinterland stretching even into Hungary. Ellwangen's experience also suggests how and in what form other abbeys may have mobilised their forces. When the Swabian town league in October 1430 received details from the assembly at Nuremberg about the contingents that they would need to muster for next summer, they sent representatives to discuss 'the call against the Hussites' to the abbeys of Kempten, Kaisersheim, Königsbronn, Weingarten, Salmansweiler, Schussenried, Murbach and Ellwangen. $9^{6}$ All of these abbeys appeared on the muster lists for the campaign the following year, and the Swabian town league no doubt wanted to discuss the arrangements for the forthcoming campaign with fellow participants. 97 These abbeys, just like Ellwangen, needed to raise a military contingent, and it is probable that Konrad's accounts can serve here as a proxy, pointing to how institutions in the same region and of similar status and standing went about raising their own forces, evidence for which has not survived.

Just who manned Ellwangen's contingent remains unclear. Over twenty gulden was spent paying 'gesellen' (best translated as 'assistants' or 'journeymen') to accompany the wagons 'to Bohemia' ('gen Behem'), but the only named individual-equipped at least with a steed and swordwas the aforementioned 'Slumpen', whose first name is noted elsewhere in Konrad's accounts as 'Heintzen'. The abbey's armed men would have been well dressed, whoever they were, for Konrad paid a clothworker to make special hats for those who went 'against the Hussites' ('an die hussen'). $9^{8}$ Similar uncertainty surrounds the performance of Ellwangen's force in the campaign that ended in defeat in mid-August.99 There is no doubt that they went to Bohemia, and there is no indication that Ellwangen's contingent was to be siphoned off from the main force for the defence of the locality. An entry for expenses in a later accounting year refers in past tense "to the canvas that one purchased and used for the Hussite campaign and which was taken to Bohemia'. ${ }^{100}$

95 Bleicher, 'Kriegsführung und Kriegsalltag', 247-8.

$9^{6}$ DRTA ix, no. 381 , pp. $479-8$ o. 97 DRTA ix, no. 408, pp. 530-1.

$9^{8}$ StAL, V/9, fo. $55^{\text {r. }}$.

99 On the campaign see Whelan, 'Walter of Schwarzenberg', 324-33.

100 'an die lÿnwat die man zü der Hussen raiß kaufft und vermacht, und gen Beheim gefürt hat': StAL, V/9, fo. $53^{\text {r. }}$ 
Once mobilised, Ellwangen's wagenburg of three lances was too small to operate on its own, so it would probably have joined onto a larger Swabian detachment once at Nuremberg - perhaps the bishop of Augsburg's or, perhaps in light of the abbey's contacts with the count of Helfenstein, the city of Augsburg's contingent which he captained - obscuring their identity in any contemporary correspondence and chronicles describing the course of the campaign. This point warrants further comment, for it highlights how even the larger contingents that formed an already heterogeneous imperial force in 1431 were far from homogeneous themselves, formed as they were of a multitude of smaller contributors. Coordinating such a varied and diverse force and maintaining order and discipline while on campaign must have been exceedingly difficult. An eyewitness account of the imperial force's defeat near Domažlice in August observed that Catholic soldiers deserted en masse on the morning of the battle even before the Hussites attacked, and went on to emphasise the division and confusion that afflicted the force, having noted earlier in the campaign the differences in opinion that had previously split 'the lords' in nominal command of the expedition. ${ }^{101}$ Ellwangen's accounts serve as a reminder to historians that the imperial force was largely composed of a host of smaller players bringing a few lances to the field each, and it is against this background that we should understand the confusion and lack of coordination that beset the crusading armies and why they repeatedly failed to make their superior numbers count in the field. ${ }^{102}$

\section{IV}

The abbey raised the Hussite tax, hosted Sigismund and outfitted a military force for war, but the outlay did not stop there, and it is important to situate Ellwangen's costs against the broader backdrop of expense and financial obligation borne by the institution during the Hussite wars. Most noteworthy in this respect were the expenses involved in receiving and dispatching messengers and, where necessary, more senior members of the abbey to meetings and negotiations. The need to send several messengers or fully-fledged representatives simultaneously to different locations reflects the decentralised nature of imperial military organisation during the latter phase of the Hussite wars, with the margrave of Brandenburg and his court organising the major campaigns, usually in the vicinity of Nuremberg, and local lords in adjoining regions overseeing the prosecution of 'daily war' ('tegliche krieg'), who mobilised forces in localities on a near constant footing to guard against Hussite incursions and attempt

${ }^{101}$ For further analysis see Whelan, 'Walter of Schwarzenberg', 331-2.

102 Šmahel, Die Hussitische Revolution, iii. 1520. 
raids of their own. ${ }^{103}$ To these should be added the regular assemblies in Nuremberg where matters concerning the Hussites were discussed, and where abbeys such as Ellwangen needed representation.

Taking a snapshot running from February 1431 through to June 1431 highlights the abbey's scramble to keep informed of developments at the margrave's court in Cadolzburg, of the negotiations in Nuremberg, and attempts to stay abreast of local initiatives for defence. In early February Leo was sent to Cadolzburg to treat with the margrave 'to find out about the Hussites', at roughly the same time as the abbey dispatched two other members of the community, a certain 'Hebenboden' and 'Stehelin'. Stehelin went with letters to Nürtingen similarly 'to find out about the Hussites' ('zuverkünden von der Hussen wegen'). ${ }^{104}$ The counts of Württemberg had the previous summer chosen Nürtingen as the site of negotiations to agree a common plan with Swabian towns for the defence against the Hussites, and it is likely that discussions there regarding that issue had resumed. ${ }^{105}$ Hebenboden was also sent to Cadolzburg to discuss Hussite matters, but was then to proceed on to meet the abbot's brother. After his return from Nürtingen, the abbey sent Stehelin straight back to Nürtingen again, presumably to discuss the Hussites further. ${ }^{106}$ In late April Leo was sent to Nördlingen to discuss matters with Count Hansen of Helfenstein. ${ }^{107}$ As the count of Helfenstein was to captain Augsburg's military contingent that summerindeed, the contingent to which Ellwangen's company may have attached itself - Hussite matters were probably discussed here too. ${ }^{108}$ Straight afterwards, Leo went to Nuremberg to arrange accommodation for Hansen, who arrived shortly thereafter, and who proceeded to split his time between Nuremberg and wherever the margrave happened to be, while Leo continued his perambulations, visiting the abbot's brother in Ansbach before returning to meet with the margrave and then Hansen once again. ${ }^{109}$

Keeping informed of events and taking part in negotiations entailed costs beyond the dispatch and receipt of messengers and the expenses for journeys made in person by members of the abbey's community. When Leo visited the margrave of Brandenburg 'to find out about the Hussites' in Cadolzburg in February 1431, he took along a falcon ('Federspil') worth over six shillings as a gift. ${ }^{10}$ The previous June, Abbot Holzingen had arranged for an individual in Crailsheim to deliver

\footnotetext{
103 On the distinction between the forms of warfare see Bleicher, 'Kriegsführung und Kriegsalltag', 235-6. For the quotation 'daily war' ('tegliche krieg') in context see Whelan, 'Between papacy and empire', $25^{-6}$.

${ }_{105}$ DRTA ix, no 311, pp. 401-2. ${ }_{106} \mathrm{StAL}, \mathrm{V} / 9$, fo. $27 \mathrm{r} .{ }_{107}$ Ibid. fo. $38 \mathrm{r}$.

${ }_{108}$ DRTA ix, no. 426, p. 560 . This document is discussed in Whelan, 'Walter of Schwarzenberg', 326-9. ${ }^{109}$ StAL, V/9, fos 38r-39r. ${ }^{10}$ Ibid. fos $25^{\mathrm{V}-26 \mathrm{r}}$.
} 
to the margrave two wagons filled with wine as a courtesy ('dienst wein'), at the cost of six pounds and seven and a half shillings. ${ }^{11}$ Similarly, plying Neithart for advice about the Hussite tax across spring and early summer 1429 came with other obligations, especially as they both continued asking for Neithart's counsel to the extent that by mid-summer the latter needed to send two books over for their perusal along with his usual letters of advice ('mengerlay ratts schraib'). ${ }^{12}$ On 5 August that year, therefore, Konrad made clear his appreciation for the priest's advice and paid five shillings for a servant to deliver to Neithart a sparrowhawk ('Sperber'), receipt of which was taken by his brother. ${ }^{113}$ Holzingen later gifted the brother a new crossbow ('ein news armprost') worth two Rhenish gulden. ${ }^{114}$ Konrad also sent Leo to Count Friedrich of Helfenstein bearing the gift of a goshawk ('mit einem habich') worth five shillings. ${ }^{15}$ The undated entry falls in the accounting year between April 1430 and 1431 , but was probably made in the spring of 1431 when Leo met the aristocrat and when it was presumably known that the count was to command Augsburg's contingent that summer.

Other expenses related to the Hussite wars recur, attesting to the diverse costs that came with sourcing information at a diplomatically sensitive time. In the summer of 1430 Konrad paid twelve and a half shillings to the bishop of Würzburg's herald to declare who had laid down their lives, including, one presumes, those who had perished in recent campaigning against the Hussites. ${ }^{116}$ Similarly, when the count of Cilli ('graven von Zale') visited the abbey on his way to join the campaign in spring/ summer 1431 ('when he rode against the Hussites'), the count's piper was given one gulden. ${ }^{117}$ One of the more unusual expenses associated with the Hussites affairs was Konrad's (undated) payment of three shillings and nine pence to the 'Nightingale', Duke Ludwig VII of Bavaria's court singer. ${ }^{118}$ The 'Nightingale' visited the abbey at some point in the accounting year between 12 March 1434 and 25 March 1435, bearing a letter from 'the Schoolmaster of Bopfingen, within which were written the Hussite articles'. ${ }^{19}$ The debates raging between Bohemian and Catholic parties

111 Ibid. fo. 34 r.

112 Ibid. fo. $8 \mathrm{v}$.

113 Ibid.

114 Ibid. fo. $15 \mathrm{v}$.

115 Ibid. fo. $26 \mathrm{r}$.

116 Ibid. fo. 33 r.

117 Ibid. fo. 57 r. This undated expense is entered into the accounting year running between 26 March 1432 and 1 April 1433, but was probably made the year before. On the younger count of Cilli's campaigning in summer $143^{1}$ see DRTA ix, no. $4^{12}$, p. 545 .

${ }_{118}$ 'Item iii $\mathrm{s}$ ix heller dem Nachtigall bracht ein brief vom schulmaister von Bopfingen, dar inn der hussen artickel geschriben waren': StAL, V/9, fo. 73v. On the Nightingale's membership of the Bavarian court see DRTA ix, no. $288 \mathrm{a}$, p. 370 n. 2.

119 On the Articles of Prague see Pavel Soukup, "The waning of the "Wycliffites": giving names to Hussite heresy', in J. Patrick Hornbeck and Michael van Dussen (eds), Europe after Wyclif, New York 2017, 196-226, esp. pp. 204-7, 210-11, 215,225 n. 56 . For a translation of the articles see Thomas A. Fudge, The crusade against heretics 
at Basle no doubt encouraged contemporaries to gain access to Hussite literature and the ideas contained within, Ellwangen's monastic community included. Seen from another angle, the dissemination of Hussite tracts and associated literature across Christendom has generated a vast bibliography, with scholars debating in minute detail the people and forces responsible for conveying such texts across Europe. ${ }^{120}$ Curiously enough, never have singers entered the analytical frame. Konrad's account book not only points to a lucrative ancillary role that a court singer could perform in southern Germany, but paints the circulation of Hussite tracts in a fresh light, as it does so many other aspects of the Hussite wars.

Konrad's accounts offer a unique perspective on how an ecclesiastical institution experienced the Hussite wars, and on the many different facets of this experience: in raising the Hussite tax, entertaining a royal visitor and equipping a military contingent for war, to even paying singers for copies of Hussite literature. From a wider perspective, Konrad's account books point to how a smaller institution within the empire responded to the intensification of the networks of alliance and cooperation forced on the region by the Hussite wars, and how an abbey of relatively modest means was able to negotiate the fraught military and political environment. ${ }^{121}$ The value of Ellwangen's financial materials assumes yet greater significance when they are placed in their regional context, for they also shed light on how the many other comparable communities and institutions across the southern and eastern stretches of the empire experienced the Hussite wars. Scholars have looked to the 'general structural problems of the Empire' to explain the supposed failure of the Hussite tax, the lax response to calls for military mobilisation and the generally poor response of the empire to the Hussite threat in military and diplomatic terms. ${ }^{122}$ The experience of Ellwangen shows these apparent failures in a new light, and Konrad's accounts points to the abbey's continued ability to meet its imperial obligations in the face of often significant logistical, financial and diplomatic challenges. Although references to the Hussite wars recur throughout Konrad's accounts, they never dominate proceedings, and by 1433-4 things began to return to normal. In July 1434, for example, Leo, one of Konrad's colleagues, who in previous years had treated with

in Bohemia: sources and documents for the Hussite crusades, Farnham-Burlington, VT 2002, no. 26.

${ }^{120}$ As an introduction to the topic see Michael van Dussen, From England to Bohemia: heresy and communication in the later Middle Ages, Cambridge 2012 , esp. chs. iii, iv.

${ }^{121}$ Hardy, 'An Alsatian', 209-11.

122 Quotation from Bleicher, 'Kriegsführung und Kriegsalltag', 247. For similar comments attributing the failure of the Hussite tax 'to structural problems' see Kaar, Wirtschaft, 6o. Spengler similarly refers to the 'political structures of the Empire' when explaining the failure of the campaign in 1431: 'Der Nürnberg Tag', 78. 
the margrave of Brandenburg, delivered a goshawk to the count of Helfenstein, and had arranged for Hansen's accommodation in Nuremberg, was instead returned to more usual tasks, and sent to nearby Weisenbach to oversee the grape harvest. ${ }^{123}$ It was no doubt a great relief to Ellwangen's monastic community - as, no doubt, to communities across the region-that battle with the Hussites would no longer be waged on the fields of the southern and eastern stretches of the Holy Roman Empire, but instead in the debating chambers of the Council of Basle. 